By Nancy Birdsall \&

Amar Hamoudi

\title{
Abstract
}

Levels and changes in the value of exports and imports divided by aggregate GDP (the trade/GDP ratio) are occasionally used as measures of trade "openness." The oft-quoted work of Dollar and Kraay (2001) and the World Bank (2002) uses changes in the trade/GDP as a basis for classifying countries as "globalizers" or "non-globalizers." We argue that neither the level nor the change in a country's trade/GDP ratio can be taken as an indication of the "openness" of a country's trade policy. In particular, we examine the ways in which terms of trade shifts have affected trade/GDP ratio over the past two decades. While commodity prices were high in the early 1980s, commodity producing countries financed large trade deficits with expected export revenue. When the prices collapsed, their capacity to import fell precipitously and they were forced to close their trade deficits in order to balance the current account. Since the numerator of the trade/GDP ratio includes the sum of exports and imports, and the denominator includes the trade balance, this adjustment resulted in a decline and then stagnation in the trade/GDP ratio. Therefore, using stagnant or declining trade/GDP ratios to identify countries that are less "open" systematically picks out those countries that are highly dependent on commodities for their export revenue. Because these same countries have experienced stagnant or negative economic growth over the past two decades, the empirical evidence offered by Dollar and Kraay overstates the importance of trade policy in economic growth. Adding a "commodity dependence" dummy variable to their growth regressions reduces the magnitude of the apparent "growth effect" of their "openness" variable at least by half. We briefly review the literature on the relationships between commodity dependence and slow growth, highlighting that the whole question of "openness" vs. "closedness" is orthogonal to the problems of poor, slow growing, commodity producing countries. 



\section{Commodity Dependence, Trade, and Growth: When "Openness" is Not Enough}

Nancy Birdsall

Amar Hamoudi

In "Trade, Growth, and Poverty," Dollar and Kraay (2001) address the "counterfactual question, what can we expect to happen when developing countries liberalize trade and participate more in the global trading system?" (p.6) They conclude based on their analysis that globalization has been good for the poor. They claim that policy changes in certain countries since the early 1980s to foster integration have led to faster economic growth, and this growth has improved the living standards of millions of the world's poorest people. ${ }^{2}$ In this paper, we show that the evidence they present does not bear out benefits of "participat[ing] more in the global trading system." The exception we take to their argument, while framed here in methodological terms, has deep practical and policy implications. ${ }^{3}$

Dollar and Kraay relate growth in countries' per capita output during the 1980s and 1990s on one hand to changes in the trade/GDP ratio on the other. The trade/GDP ratio has been called a measure of "trade openness"-although as we will show it is nothing of the kind. They label the 24 countries in their sample whose trade/GDP ratios increased most dramatically over the 1980s

\footnotetext{
${ }^{1}$ The authors are grateful to William Cline, William Easterly, Ricardo Hausmann, Aart Kraay, Sarah Lucas, Dani Rodrik, and Staci Warden for very helpful comments on earlier drafts. Our gratitude should not be taken to implicate them in any of our errors, omissions, or oversights.

2 This is not to say that Dollar and Kraay were the first—or even among the first— to marshal empirical evidence in the "globalization debate." Among the more recent and widely quoted works from the enormous empirical literature are Dollar (1992), Sachs and Warner (1995), and Frankel and Romer (1999), not to mention dozens of books and any number of case studies. Few of these have received as much attention among non-technical audiences and the popular media as "Trade, Growth, and Poverty."

${ }^{3}$ The World Bank (2002) quotes Lindert and Williamson in implying that methodological exceptions to the "trade causes growth" literature are pedantic and dangerous. "The doubts that one can retain about each individual study threaten to block our view of the overall forest of evidence," they warn. "[T]here are no anti-global victories to report for the postwar Third World." This could have made a valid warning to those few countries which emerged from colonialism conflating autarky with independence, but it certainly can not be used as a "pro-globalist" argument. "Anti-globalism" and "pro-globalism" are not communally exhaustive.
} 
and 1990s as "globalizers" and the remaining 44 countries as "non-globalizers." They find that the "globalizers" grew faster than the "non-globalizers."

Dollar and Kraay focus on the change rather than the level of the trade/GDP ratio, noting that the latter is likely to be more a product of a country's initial conditions than of policy. Since initial conditions only occur once, Dollar and Kraay reason that they can "control" for them by differencing countries' trade/GDP levels between time periods. Any observed increases in the trade/GDP ratio can then be taken to be the result of policies which foster openness. ${ }^{5}$ This reasoning is valid as long as the effects of initial conditions are the same in every period. However, there are factors beyond the control of policy makers whose effects vary with time.

\section{Because of these factors, the change in the trade/GDP ratio is a poor proxy for government}

policy unless the analysis explicitly controls for them in some way.

Particularly important among factors beyond policy makers' control may well be geographical, historical, and institutional conditions that incline countries toward a large share of natural resources and primary commodities in their exports. ${ }^{6}$ The effect of these factors on the trade/GDP ratio obviously varies over time with the current and expected future world prices of exports on which countries depend. In principle, of course, countries can be expected to adjust their production mix over the long run to changes in relative prices. However, a change in long run price trends may not be predictable, and even if it is, adjustment takes time.

Below we show that most of the "non-globalizers" were highly dependent on natural resources and primary commodities for their export revenues in the early 1980s, while most of the "globalizers" were not. In retrospect, the early 1980s marked a distinct break in the trends of

\footnotetext{
${ }^{4}$ They also discern a dose-response relationship, such that every increase of one one-hundredth in the trade/GDP ratio over a decade comes with about half a percentage point faster annual growth in income per person, even after considering other factors like macroeconomic and political stability. Most of the countries in the sample-in fact, over three quarters - experienced changes in trade/GDP which were smaller in magnitude than one one-hundredth. (We say "one one-hundredth" rather than "a percentage point" because trade/GDP is not a proportion; the sum of exports and imports is not a component of GDP.)

${ }^{5}$ Dollar and Kraay say they "use decade-over-decade changes in the volume of trade as an imperfect proxy for changes in trade policy" (emphasis in original), and that "[b]y focusing on. . changes in trade volumes [as opposed to levels] we can at least be sure that our results are not driven by geography, nor by any other unobserved country characteristic. .." (p.3). As we note below, they have modified these claims somewhat in recent statements.

${ }^{6}$ Think of these as a vector of characteristics which at any given time will incline a country toward a large share of primary commodities and natural resources in its "expected" future export revenue stream.
} 
commodity prices, trade/GDP ratios, and output per person. Although there remains some controversy over the existence of any long run trend, ${ }^{7}$ it is not controversial that the dramatic declines in commodity exporters' terms of trade which took place in the early 1980s represented a qualitative break from past patterns. The World Bank (2001) reports that the ratio of nonenergy commodity prices to manufactured goods prices, which had been virtually constant from 1960 to 1980 , declined by 45 percent from 1980 to the late 1990s. The collapse in energy prices since the booms of the late 1970s has been particularly dramatic. Between 1960 and 1980, nominal energy prices had increased far faster than manufactured goods, but then declined by 76 percent between 1980 and the late 1990s. Figure 1 reproduces a World Bank graph indicating these trends.

${ }^{7}$ Since the early 1950s, most of this controversy has focused not only on the question of whether changes in the relative prices of commodities have been truly secular (rather than random shocks around a constant mean), but also on questions about the method for calculating valid price indices. However, neither of these important questions is relevant in this particular context. 


\section{Figure 1}

Figure 4.1 Primary commodity prices versus manufactures unit value index (MUV),1960-98

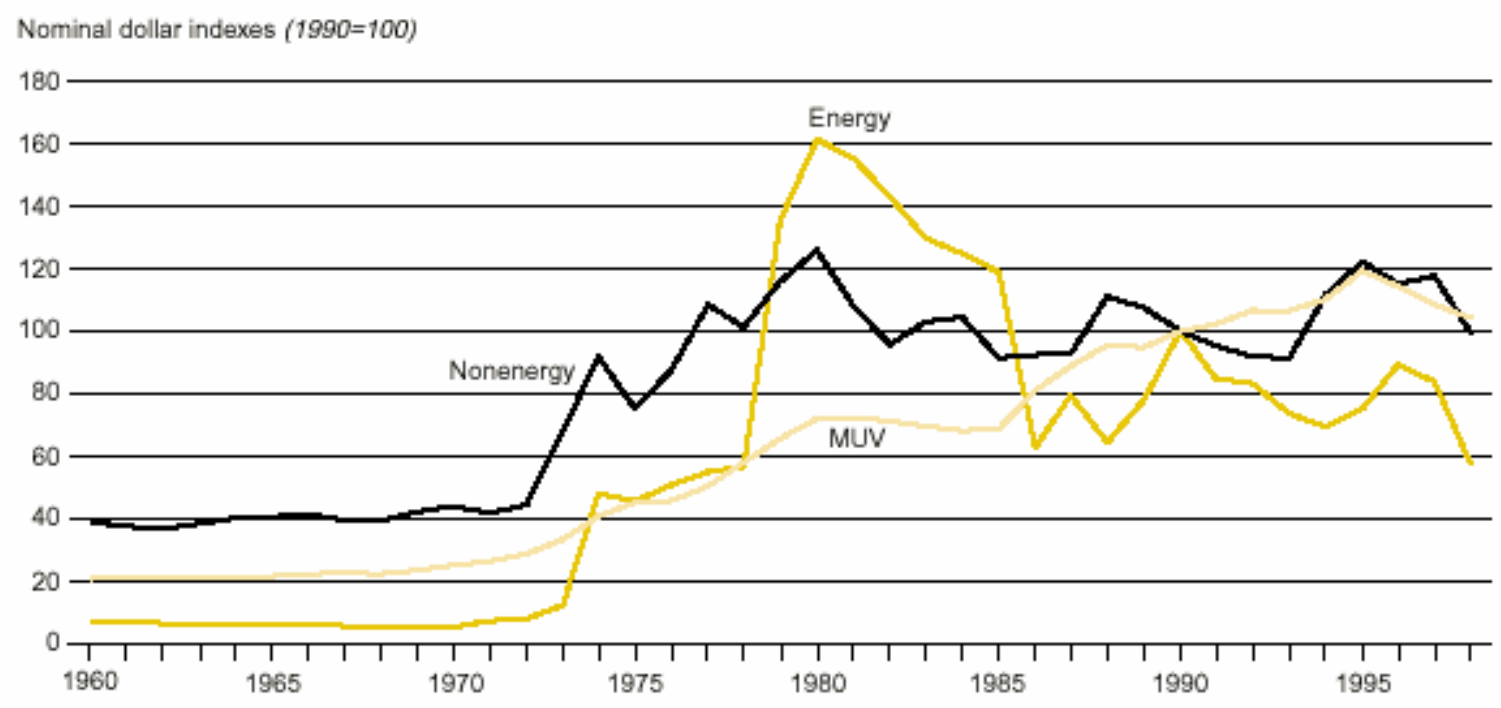

Source: World Bank staff calculations.

Notes: Reproduced from World Bank (2001)

Until the early 1980s, the "non-globalizers" had higher trade/GDP ratios than the "globalizers" because the prices of their exports were relatively high (see figure 2). Given their expected export revenue stream, they were able to finance modest and growing trade deficits. In the early 1980s, when the prices of their primary commodity exports collapsed suddenly, their export revenue and capacity to import collapsed as well. Meanwhile, the relative prices of the manufactured exports of the "globalizers" have increased, so they have appeared to grow more "open." The apparent stagnation in the "openness" of the non-globalizers and increase in the "openness" of the globalizers in part reflects these changes in the structure of world prices. That is our first point. 


\section{Figure 2}

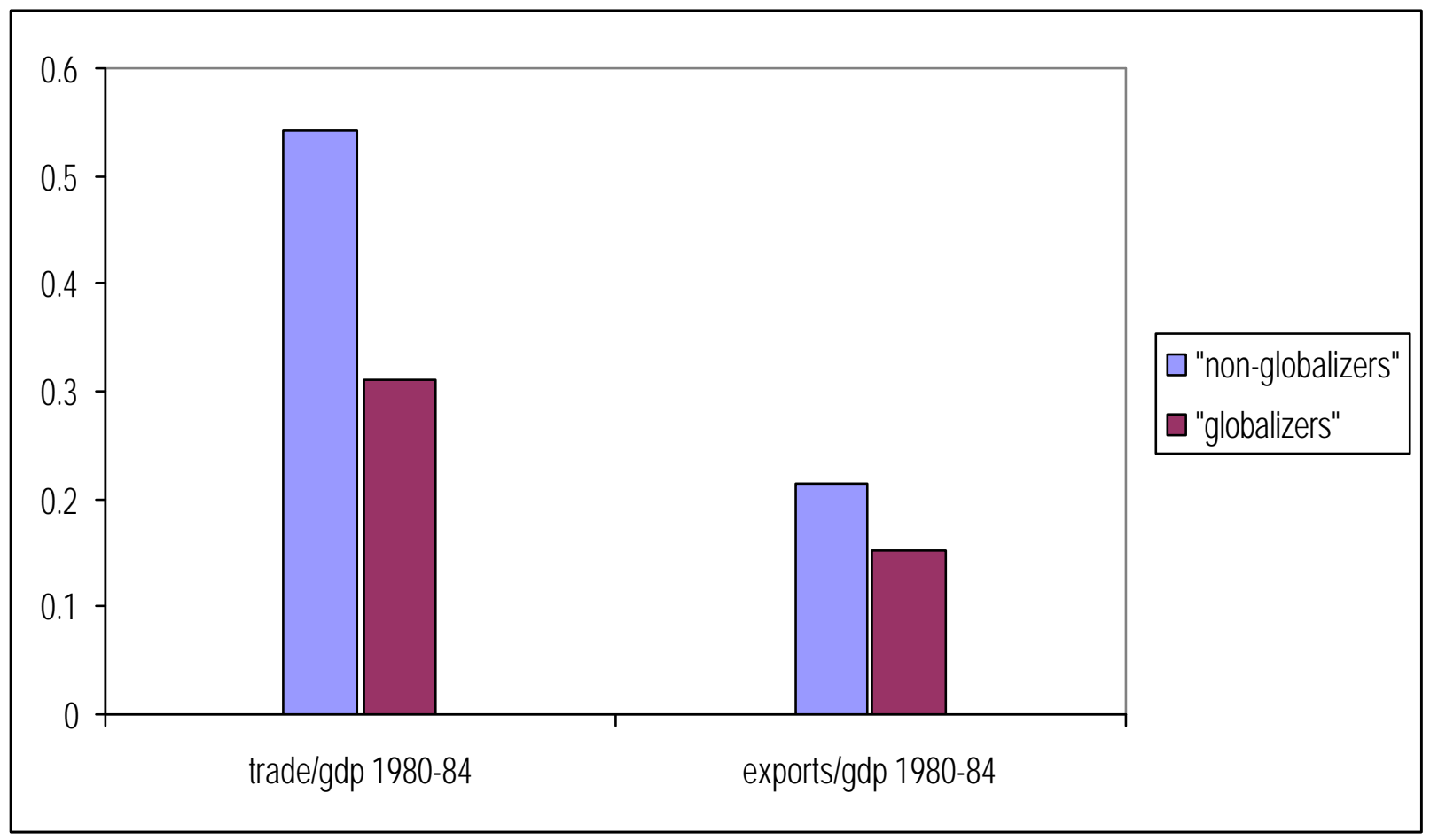

Notes

Indicates the population-weighted average trade/GDP ratio and exports/GDP ratio during the early 1980s in the groups of countries labeled by Dollar and Kraay as "globalizers" and "non-globalizers." Dollar and Kraay use changes, not levels, of the trade/GDP ratio to indicate "openness." However, the figure indicates that the so-called "non-globalizers" were certainly participating in global trade at the beginning of the period of Dollar and Kraay's analysis. The trade/GDP and export/GDP ratios are calculated using import, export, and GDP data from World Bank (2001a). For more details, see text.

Furthermore, these same changes in relative prices, not necessarily anything to do with trade policy, help explain differences in the growth of output per person. Dollar and Kraay have not isolated the benefits of "participat[ing] more in the global trading system," but rather the "curse" of primary commodity dependence! ${ }^{8}$ That is our second point.

Commodity dependence of certain forms may have more to do with geographical characteristics and social and political history than with countries' policies regarding integration with the rest of the world. Countries with high natural resource and primary commodity content in their exports are not necessarily "closed" nor have they necessarily chosen to "participate more in the global

\footnotetext{
${ }^{8}$ The word "curse" here is stylized, simply reflecting the fact that most commodity dependent countries experienced slow or negative growth in the 1980s and 1990s. As we discuss below, there is disagreement about the dynamics which give rise to this empirical regularity.
} 
trading system." For them, reducing tariffs and eliminating non-tariff barriers to trade may not lead to growth. In this context, terms like "openness," "liberalization," and "globalization" are red herrings. The causes and effects of natural resource dependence are complex, and most of the issues involved in designing policies to deal with them are orthogonal to the "globalization debate." 9

Of course, to some extent changes in trade/GDP (and primary commodity export dependence) are the result of policy. But as Rodrik (2001) has argued the scope of policies involved is enormous, including all those that have to do with development; a stagnant trade/GDP ratio, like slow growth in output per person, usually indicates that a problem exists. It does not indicate what this problem is, nor even whether it can be fixed through policy reform. ${ }^{10}$

We are not arguing in favor of closure to international trade- the division of labor, after all, is limited by the scope of the market, and autarky is incontrovertibly immiserizing. But the claim that "globalization is good for the poor"- - just like the claim that it "hurts the poor"-is not helpful to those many countries who are already reasonably "open" but still struggling with what Easterly (2001) calls "the elusive quest for growth.",1

We proceed in four parts. In the next section we define our alternative classification of countries as "most" or "least" commodity dependent and compare that grouping to Dollar and Kraay's

\footnotetext{
${ }^{9}$ The World Bank (2002), drawing on the results presented by Dollar and Kraay, argues that these issues are not orthogonal at all, but rather that countries can diversify production by "breaking into global markets for manufactured goods and services." They imply that the process of "globalizing" results in diversification of production away from commodities. However, they offer no evidence to justify this claim. Another study by de Ferranti, Perry, Lederman, and Maloney (2002) argues that part of a proper strategy for diversifying production in natural resource rich countries involves "openness to trade, market access, and FDI flows." However, the evidence they present to justify this claim relies heavily on Mexico's experience after NAFTA. This is probably a special case, however, since Mexico is unique in that it shares a 1000 mile border with the world's largest market. The authors also note that such a strategy involves improvements in education, infrastructure, and governance, as well as publicly supported research and development—none of which relate to "openness."

${ }^{10}$ For example, in a more recent discussion Dollar and Kraay (2002) enumerate certain "globalization measures such as trade and investment flows, tariff rates, and the presence of capital controls." It is difficult to see how the first of these can reasonably be described as a "measure."

${ }^{11}$ Other criticisms have been leveled against Dollar and Kraay's analysis. Rodrik (2001; 2002), argues in part that integration is a result of economic growth, and not a cause, and explores at greater length the enormity of the scope of policies beyond simple trade liberalization that affect the level of trade. In this note we focus on the point that some countries have experienced slow growth in income per person and stagnant trade/GDP ratios since the early 1980s not because of incompetence or excessive populism or xenophobia, but because of changes in the structure of world prices, which were beyond their control.
} 
"globalizers" and "non-globalizers." We then show the trend in the trade/GDP ratio since the 1960s for the two categories. In Section III we explore the relationship between commodity dependence and growth, using the growth regression of Dollar and Kraay, to which we add variables indicating commodity dependence. The final section concludes on a note of agnosticism—regarding at least one policy implication that cannot be drawn.

\section{Commodity dependence and trade/GDP ratios}

The trade to GDP ratio is, to say the least, a highly idiosyncratic statistic. ${ }^{12}$ It is sometimes described as a measure of "openness." But Saudi Arabia, Bahrain, Panama, and Guyana would be among the world's most "open" economies of the 1980s by this measure, while Brazil, Bangladesh, Argentina, the United States, and Japan would be among the least. Dollar and Kraay argue that the idiosyncrasies of this statistic are primarily a result of initial conditions (location, presence of natural ports, and so on), and so they are not as troublesome when one looks at changes in the ratio over time. The isolation of a landlocked country from global transport networks obviously does not explain any observed increases or decreases in its trade/GDP ratio.

However, one set of initial conditions — commodity dependence-may explain both levels and changes in the trade/GDP ratio. Abstracting from any changes in domestic consumption and investment, a change in the ratio is driven not only by changes in the value of exports and imports themselves, but also by changes in the trade deficit (that is, the distribution of total trade

${ }^{12}$ The trade/GDP ratio is Open $=\frac{X+M}{D_{Y}+X-M}$, where $X$ represents the value of all exports, $M$ represents the value of all imports, and $D_{Y}$ represents total domestic consumption and investment (by both public and private sectors). Therefore, to highlight one of the more peculiar idiosyncrasies of the statistic, it is not difficult to notice how a country running a trade deficit, other things being equal, will be more "open" by this measure than a country running an identically sized trade surplus. This gives rise to a curiously asymmetrical property in a measure of what should surely be a symmetrical concept. Imagine a hypothetical world of two countries with identically sized domestic economies and no barriers to trade; at any given time, unless there is perfectly balanced trade between them, one of the trading partners will be more "open" than the other! This property is somewhat reminiscent of former President Clinton's definition of "sexual relations." Other (less colorful) properties derive from the fact that the measure of GDP in the denominator is not traditionally adjusted for purchasing power parity, making countries with lower relative non-traded goods prices appear more "open," and the fact that countries with small populations tend to appear more "open." 
between exports and imports). ${ }^{13}$ Running an unsustainable trade deficit will make a country appear relatively "open" until it precipitates a crisis, at which point the trade/GDP ratio will decline suddenly. Manzano and Rigobon (2001) explore the economic growth effects of the unexpected collapse in natural resource prices in the early 1980s on resource rich countries. They argue that natural resource abundant countries effectively used expected future export revenues as collateral to finance trade deficits in the 1970s. When prices collapsed in the early 1980s, these deficits became unsustainable, and during the subsequent debt crisis, they were forced to bring their current accounts back in balance quickly. Manzano and Rigobon focus on the growth effects of the price changes. Below we show that the effects of the price changes on the evolution of the trade/GDP ratio is consistent with their story.

To examine the relationship between changes in the trade/GDP and export content, we stratify countries according to the extent to which primary commodities accounted for total export revenues during the early 1980 s.

Using data on exports by single digit SITC codes for 115 developing countries and 22 industrialized countries for each year between 1980 and 1984 from the World Trade Analyzer database (Statistics Canada, 1999), ${ }^{14}$ we classified these exports as either "commodities" or "manufactures" as shown in Table 1. We then calculated, for each country in each year, the share of commodities in total exports (that is, commodities divided by the sum of commodities and manufactures).

For each year, we identified the top third of primary commodity exporters - that is, the countries whose share of commodities in total exports were greater than the $67^{\text {th }}$ percentile. Countries were labeled as "most commodity dependent" if they were among the top third of commodity exporters for at least four of the five years, and "least commodity dependent" if they were among the top third for zero or one of the five years. Among the 115 developing countries in our

\footnotetext{
${ }^{13}$ Of course, considering the trade/GDP ratio measured in current prices (as it often is) is even more problematic, since terms of trade effects will impact the ratio directly. Dollar and Kraay are careful to correct for the direct effects of price changes by using constant price ratios. However, as we argue here, the terms of trade also have important effects on the evolution of the trade/GDP ratio over time through the intertemporal budget constraint.

${ }^{14}$ The selection of 1980-84 as the "initial" period is partly a result of data availability constraints; our SITC specific export data only go back to 1980 . However, it is also justified on more intellectual grounds, because this period reflects the beginning of the recent erosion in commodity exporters' terms of trade.
} 
sample, this produces 72 "least commodity dependent" countries, 34 "most commodity dependent" countries, and 9 countries in between.

Table 1

\begin{tabular}{|c|c|c|}
\hline SITC code & Definition & Classification \\
\hline 0 & Food and live animals chiefly for food & Commodity \\
\hline 1 & Beverages and tobacco & Commodity \\
\hline 2 & Crude materials, inedible, except fuels & Commodity \\
\hline 3 & Mineral fuels, lubricants, and related materials & Commodity \\
\hline 4 & Animal and vegetable oils, fats, and waxes & Commodity \\
\hline 5 & Chemicals and related products & Manufactured \\
\hline 6 & Manufactured goods classified chiefly by material & Manufactured (except:) \\
\hline \multicolumn{2}{|r|}{$\begin{array}{l}611 \text { - Leather } \\
667 \text { - Pearls \& prec./semi-prec. stones, worked and unworked } \\
68 \text { - Non-ferrous metals }\end{array}$} & $\begin{array}{l}\text { Commodity } \\
\text { Commodity } \\
\text { Commodity }\end{array}$ \\
\hline 7 & Machinery and transport equipment & Manufactured \\
\hline 8 & Miscellaneous manufactured articles & Manufactured \\
\hline 9 & Unclassified & Excluded from all calculations \\
\hline
\end{tabular}

Notes

Indicates our classification of goods as "commodities" or "manufactured goods" based on SITC. Export volumes in each SITC were calculated for 115 developing countries and 22 industrialized countries using the World Trade Analyzer database (Statistics Canada, 1999). The 115 developing countries are those listed in table 2. The 22 industrialized countries are: Australia, Austria, Belgium, Canada, Denmark, Finland, France, Germany, Greece, Iceland, Ireland, Italy, Japan, Luxembourg, New Zealand, Norway, Portugal, Spain, Sweden, Switzerland, the United Kingdom, and the United States. For more details, see text.

Table 2 lists the countries in our sample, and indicates the overlap between our classification and that of Dollar and Kraay. Note, first, that there is a sort of "all-or-none" property to commodity dependence - countries are either "most commodity dependent" or "least commodity dependent," with only a few countries in between. This implies that the factors which determine a country's placement among the top third of the world's commodity exporters did not vary much during the first five years of the 1980s. Second, and more importantly, for those countries which are included in both our sample and that of Dollar and Kraay, the overlap between our 
"most commodity dependent" group and their "non-globalizers" group is near-perfect. Only two of our "most commodity dependent" countries (Rwanda and Mali) are on the list of "globalizers."15)

\footnotetext{
${ }^{15}$ In the case of Rwanda, the data (World Bank, 2001a; Statistics Canada, 1997) suggest that the observed change in the trade/GDP ratio between the 1975-79 period and the 1995-97 period has little to do with trade policy. Aggregate GDP in constant local terms increased until the 1985-89 period, and then collapsed sharply (by about half) between 1991 and 1994. Exports also declined steadily during the early 1990s, but the effect of this decline (in the numerator) was offset by a doubling of imports (driven mostly by an increase of about $270 \%$ in food imports) between 1986 and 1996. Therefore, it is likely that the impact of the 1994 genocide on the denominator of the trade/GDP explains more of Rwanda's "globalizer" status than does the impact of any trade policy shifts on the numerator.
} 
Table 2

\begin{tabular}{|c|c|c|c|}
\hline & $\begin{array}{l}\text { Least Commodity Dependent } \\
(1980-84)\end{array}$ & $\begin{array}{l}\text { Most Commodity Dependent } \\
(1980-84)\end{array}$ & $\begin{array}{l}\text { Neither most nor least commodity } \\
\text { dependent }\end{array}$ \\
\hline $\begin{array}{l}\frac{\infty}{\mathbb{N}} \\
\frac{N}{\bar{N}} \\
\frac{0}{0} \\
\text { 음 } \\
\frac{1}{0} \\
2\end{array}$ & $\begin{array}{c}\text { Benin; Burkina Faso; Egypt; El } \\
\text { Salvador; Fiij; Guatemala; } \\
\text { Honduras; Indonesia; Israel; } \\
\text { Kenya; Madagascar; Mauritius; } \\
\text { Morocco; Pakistan; Peru; } \\
\text { Senegal; South Africa; Sri Lanka; } \\
\text { Syria; Togo; Trinidad \& Tobago; } \\
\text { Tunisia }\end{array}$ & $\begin{array}{c}\text { Algeria; Burundi; Cameroon; } \\
\text { Central African Republic; Rep. } \\
\text { Congo; DR Congo; Ecuador; } \\
\text { Gambia; Ghana; Iran; Mauritania; } \\
\text { Myanmar; Nigeria; Papua New } \\
\text { Guinea; Sierra Leone; Venezuela; } \\
\text { Zambia }\end{array}$ & $\begin{array}{l}\text { Chad; Gabon; Guinea-Bissau; } \\
\text { Malawi; Niger }\end{array}$ \\
\hline $\begin{array}{l}\frac{N}{\mathrm{~N}} \\
\frac{N}{\mathbb{N}} \\
\frac{\mathrm{O}}{\mathrm{O}} \\
\end{array}$ & $\begin{array}{l}\text { Argentina; Bangladesh; Brazil; } \\
\text { China; Colombia; Costa Rica; } \\
\text { Cote d'Ivoire; Dominican Rep; } \\
\text { Haiti; Hungary; India; Jamaica; } \\
\text { Jordan; Malaysia; Mexico; Nepal; } \\
\text { Nicaragua; Philippines; Thailand; } \\
\quad \text { Uruguay; Zimbabwe }\end{array}$ & Mali; Rwanda & Paraguay \\
\hline 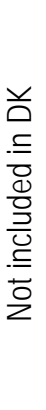 & $\begin{array}{l}\text { Afghanistan; Albania; Barbados; } \\
\text { Belize; Bhutan; Bulgaria; } \\
\text { Cambodia; Comoros; Cyprus; } \\
\text { Djibouti; Guyana; Hong Kong; } \\
\text { Kiribati; South Korea; Kuwait; } \\
\text { Laos; Lebanon; Maldives; Malta; } \\
\text { Mongolia; Mozambique; New } \\
\text { Caledonia; Panama; Poland; } \\
\text { Romania; Seychelles; St. Kitts \& } \\
\text { Nevis; Tanzania; Vietnam }\end{array}$ & $\begin{array}{c}\text { Angola; Bahamas; Bolivia; } \\
\text { Ethiopia; Guinea; Liberia; Libya; } \\
\text { Oman; Saudi Arabia; Solomon } \\
\text { Islands; Somalia; Sudan; } \\
\text { Suriname; Uganda; United Arab } \\
\text { Emirates }\end{array}$ & $\begin{array}{l}\text { Bahrain; Equatorial Guinea; } \\
\text { Yemen }\end{array}$ \\
\hline 㞼 & $\begin{array}{l}72 \text { Countries (of which } 43 \text { are } \\
\text { included in Dollar and Kraay) }\end{array}$ & $\begin{array}{l}34 \text { Countries (of which } 19 \\
\text { included in Dollar and Kraay) }\end{array}$ & $\begin{array}{l}9 \text { Countries (of which } 6 \text { included } \\
\text { in Dollar and Kraay) }\end{array}$ \\
\hline
\end{tabular}

Notes

These are the 115 developing countries in our sample, classified based on the extent of their dependence on primary commodities and natural resources in total exports during the first half of the 1980s (that is, between 1980 and 1984). SITC specific export data were collected from the World Trade Analyzer (Statistics Canada, 1999), and classified as "commodities" or "manufactures" as shown in table 1. Then, a country was defined as "commodity dependent" in a given year if it was among the top 33\% in terms of the ratio of commodity exports to total exports during that year. The cut off values for qualification as a "commodity exporter" (that is, the $67^{\text {th }}$ percentile of the ratio of commodity exports to total exports) were: in 1980, 94.4\%; in 1981, 92.8\%; in 1982, 92.2\%; in 1983, 93.0\%; and in 1984, 93.5\%. A country qualified as "most commodity dependent" if its ratio of commodity exports to total exports exceeded these values in four or five years during this period, and "least commodity dependent" if its ratio exceeded these values for zero or one year during this period. The remaining nine countries had ratios which exceeded these values for two or three years during this period. In addition to these 115 developing countries, we also collected SITC specific data for 22 industrialized countries, which are listed in the notes to table 1. These countries were not included in our calculations; however, their share of commodities in total exports was below the cut off values listed above every year between 1980 and 1985 . For more details, see notes to table 1, and text. 
In figure 3 we show the evolution in trade/GDP ratios between Dollar and Kraay's "globalizer" and "non-globalizer" groups; this is simply our reproduction of the results reported in figure 1 of Dollar and Kraay (2001). ${ }^{16}$

\section{Figure 3}

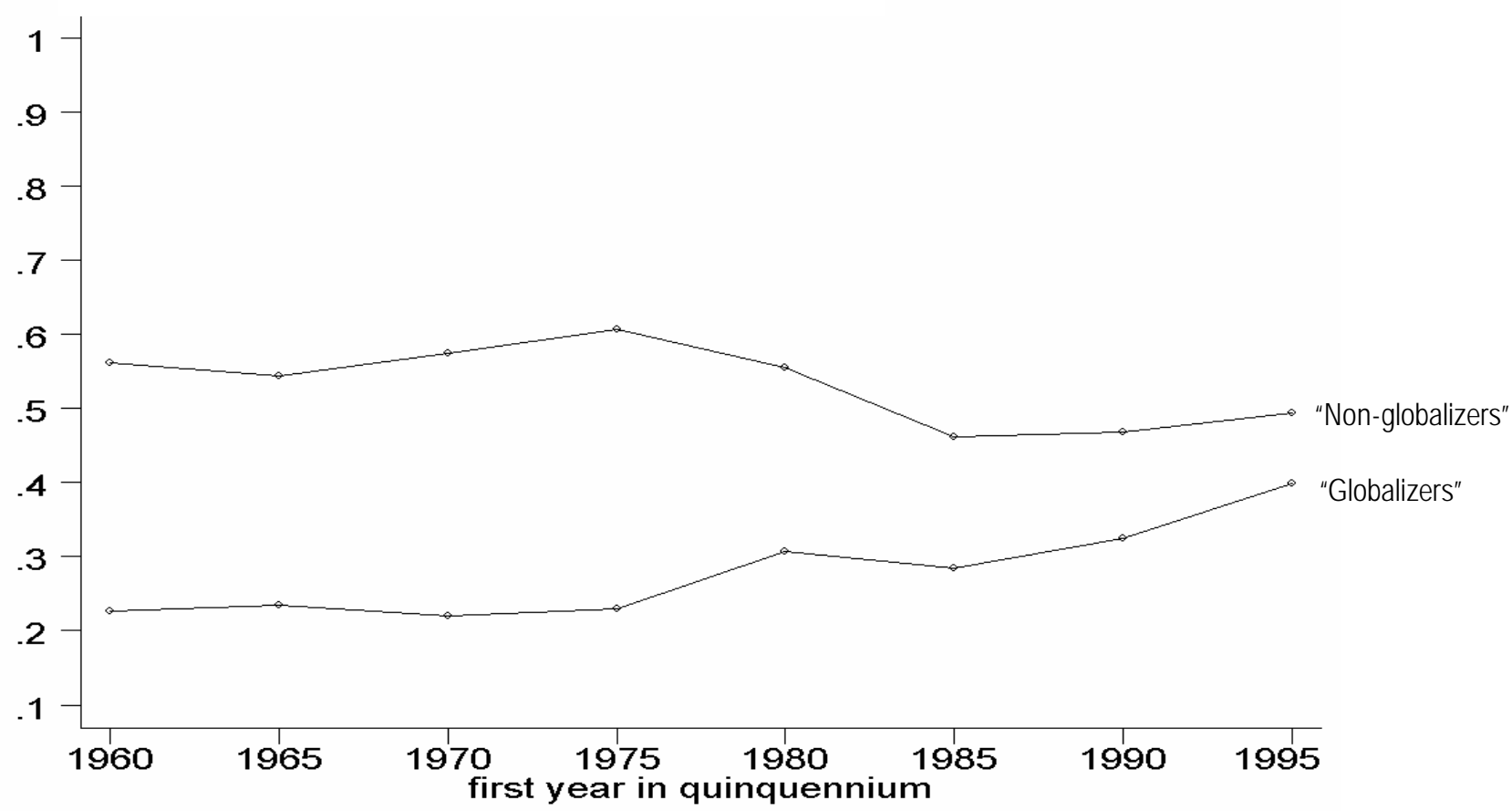

Notes

Reproduces the results reported in figure 1 of Dollar and Kraay (2001), tracing the evolution in the population-weighted average trade/GDP ratio for two groups of countries, labeled by Dollar and Kraay as "globalizers" and "non-globalizers." The quinquennial average trade/GDP ratios for each of the 24 "globalizers" and 44 "non-globalizers" were taken directly from the dataset underlying the original study, which the authors were generous to share. Populations were taken from World Bank (2001a) in order to generate population weighted averages of these country-specific trade/GDP ratios. The last time period shown in the graph is not a quinquennium, but rather the three year period 1995-1997, since Dollar and Kraay did not report data after 1997. In the labels on the $\mathrm{x}$-axis, the first two digits refer to the first year of the time period depicted, and the last two digits refer to the last year. For more details, see Dollar and Kraay (2001), and text.

Figure 4 shows the trend in population weighted quinquennial averages of the trade/GDP ratio among our "most commodity dependent" and "least commodity dependent" groups. ${ }^{17}$ The

\footnotetext{
${ }^{16}$ We also show the unweighted average in appendix figure A. We believe that unweighted averages admit of proper inferences regarding the relationships between "policy" and growth, since countries are the appropriate unit for testing policy effects. However, we use population-weighted averages in figures 3, 4, and 5 in order to keep our approach consistent with that of Dollar and Kraay; this makes our analysis more conservative with respect to our hypothesis.
} 
observed trends are consistent with the hypothesis we have outlined. In the 1960s-and even more in the 1970s — the commodity producer countries were able to finance trade deficits because their expected export revenue streams were relatively high. Then, with the collapse in the world prices of their exports in the early 1980s, they were forced to close these deficits quickly, which resulted in declines in their trade/GDP ratio.

\section{Figure 4}

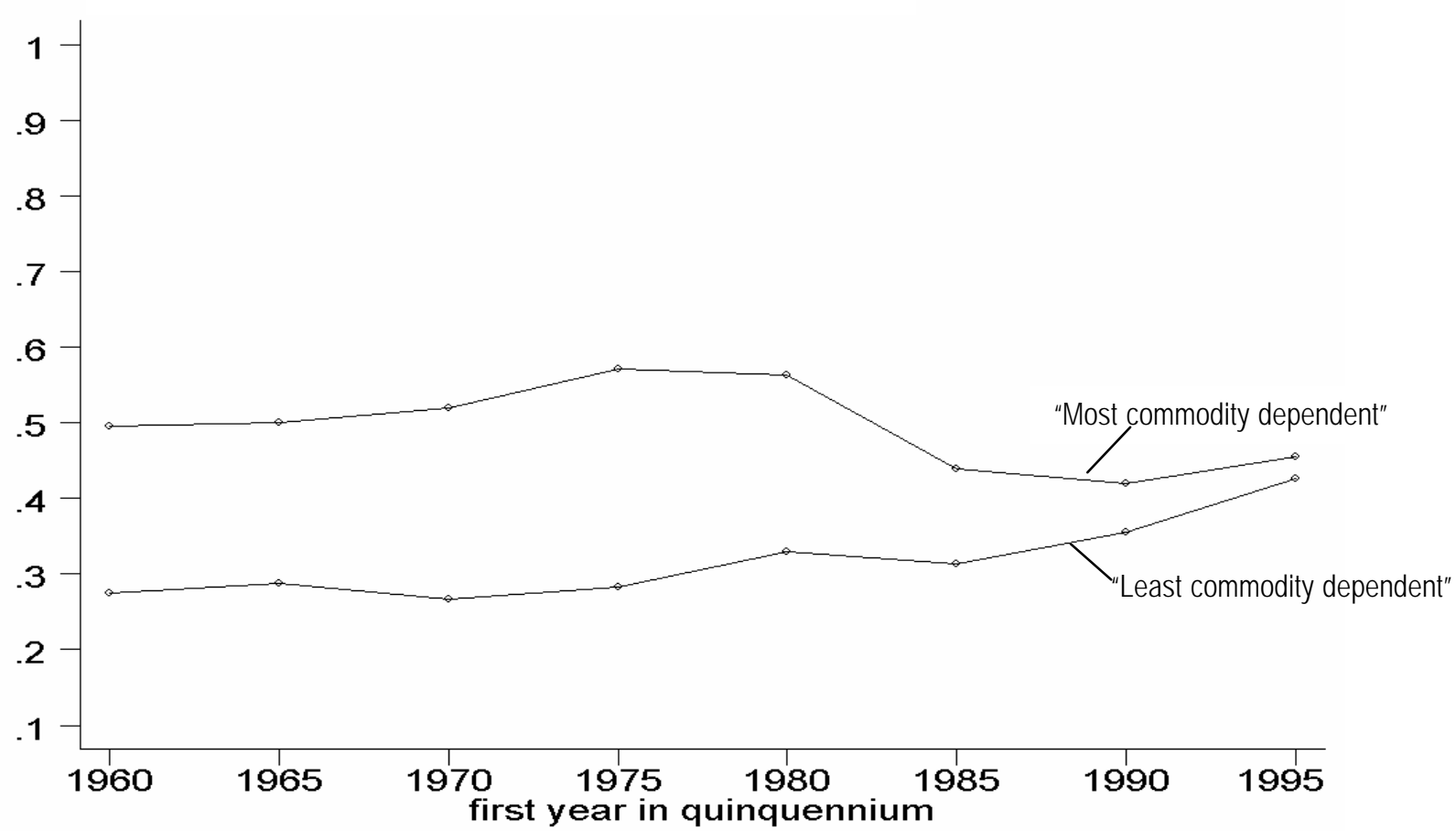

Notes

Tracks the population weighted average trade/GDP ratio in each quinquennium from 1960 to 1999 among the "most commodity dependent" and "least commodity dependent" countries, as listed in table 2. Annual trade/GDP ratios and population data were taken from World Bank (2001a). For each country, five-year averages of the trade/GDP ratio and population were calculated. Populationweighted averages of these country-specific trade/GDP ratios were then calculated for each of the categories. Data were not available for all countries in all years, and so some countries in some quinquennia are excluded from the averages shown. The list of included country-year observations is shown in appendix table C. The last quinquennium shown spans the years 1995-1999. For more details, see text.

Note the similarity in the trends depicted in figures 3 and 4. In both cases, the "non-globalizers" (or the commodity producers) have higher trade/GDP ratios throughout. Growth in the

\footnotetext{
${ }^{17}$ We also show the unweighted average in appendix figure B. For more on the use of population weights, see footnote 16 above.
} 
trade/GDP ratio is at least equal if not slightly faster among the "non globalizers" (or the commodity producers), until the late 1970 s or early 1980 s, after which they begin to converge. This similarity is not surprising; recall from table 2 that virtually all the "globalizers" in this graph turn out to have been defined as "least commodity dependent" by our criteria.

Figure 5 decomposes the observed changes in the trade/GDP ratio of our "most" and "least" commodity dependent groups, showing changes in the import/GDP and export/GDP ratios separately. ${ }^{18}$ In this graph, the emergence of trade deficits throughout the late 1970s and early 1980s among the commodity producers is clearly evident, along with the rapid closing of these deficits during the debt crisis. ${ }^{19}$

\section{Figure 5}

\section{a. Least Commodity Dependent Countries}

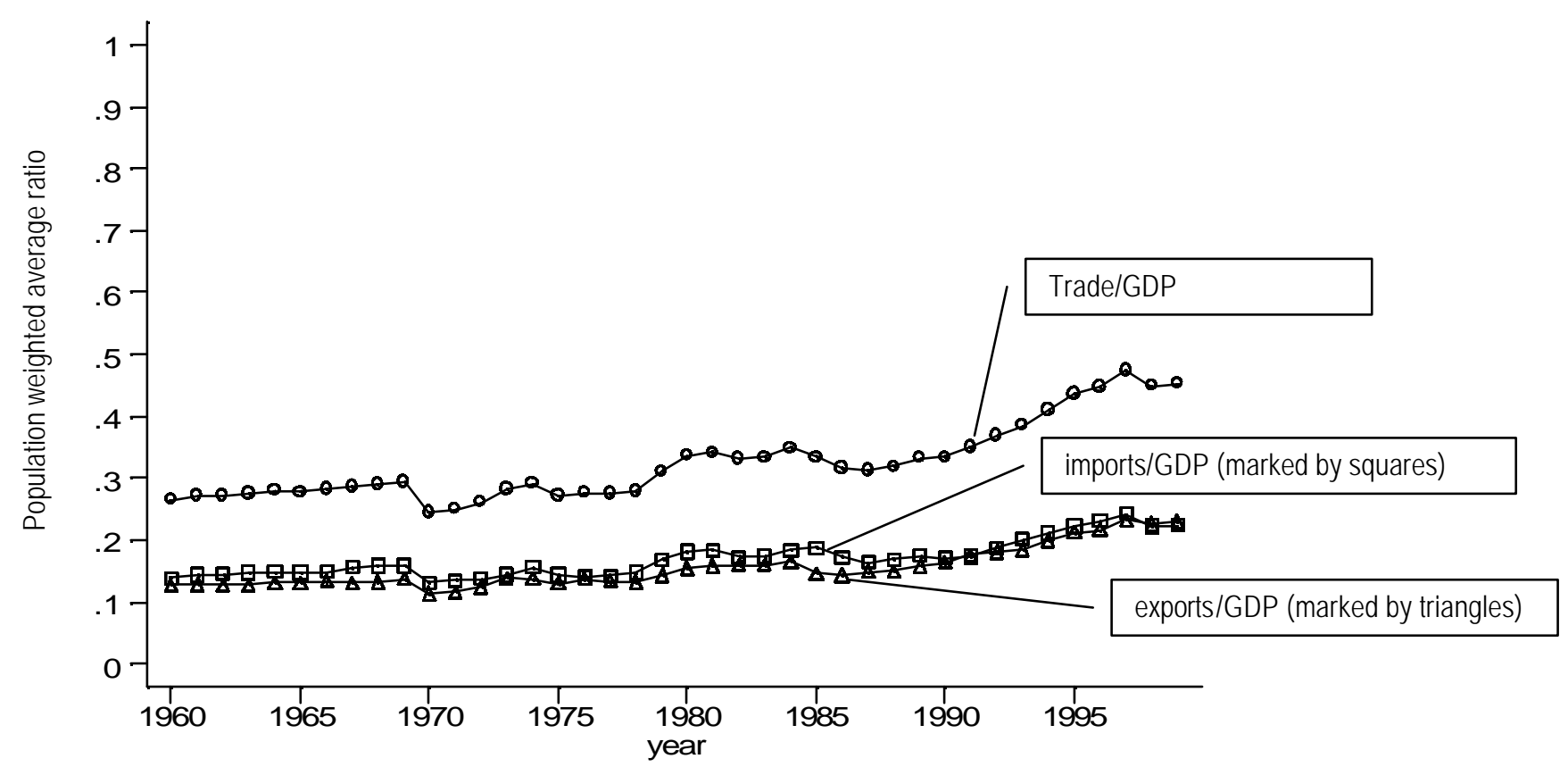

\footnotetext{
${ }^{18}$ We also present unweighted averages in Appendix Figure C. For more on the use of population weights, see footnote 16 above.

${ }^{19}$ The same patterns are observed if we stratify countries by Dollar and Kraay's “(non-)globalizer" criterion rather than our "most" or "least" commodity dependent criterion. This is not surprising, of course, given the extent of the overlap between these classifications. The graphs using Dollar and Kraay's stratification are not shown here, in the interest of conciseness, but they are available upon request from the authors.
} 


\section{b. Most Commodity Dependent Countries}

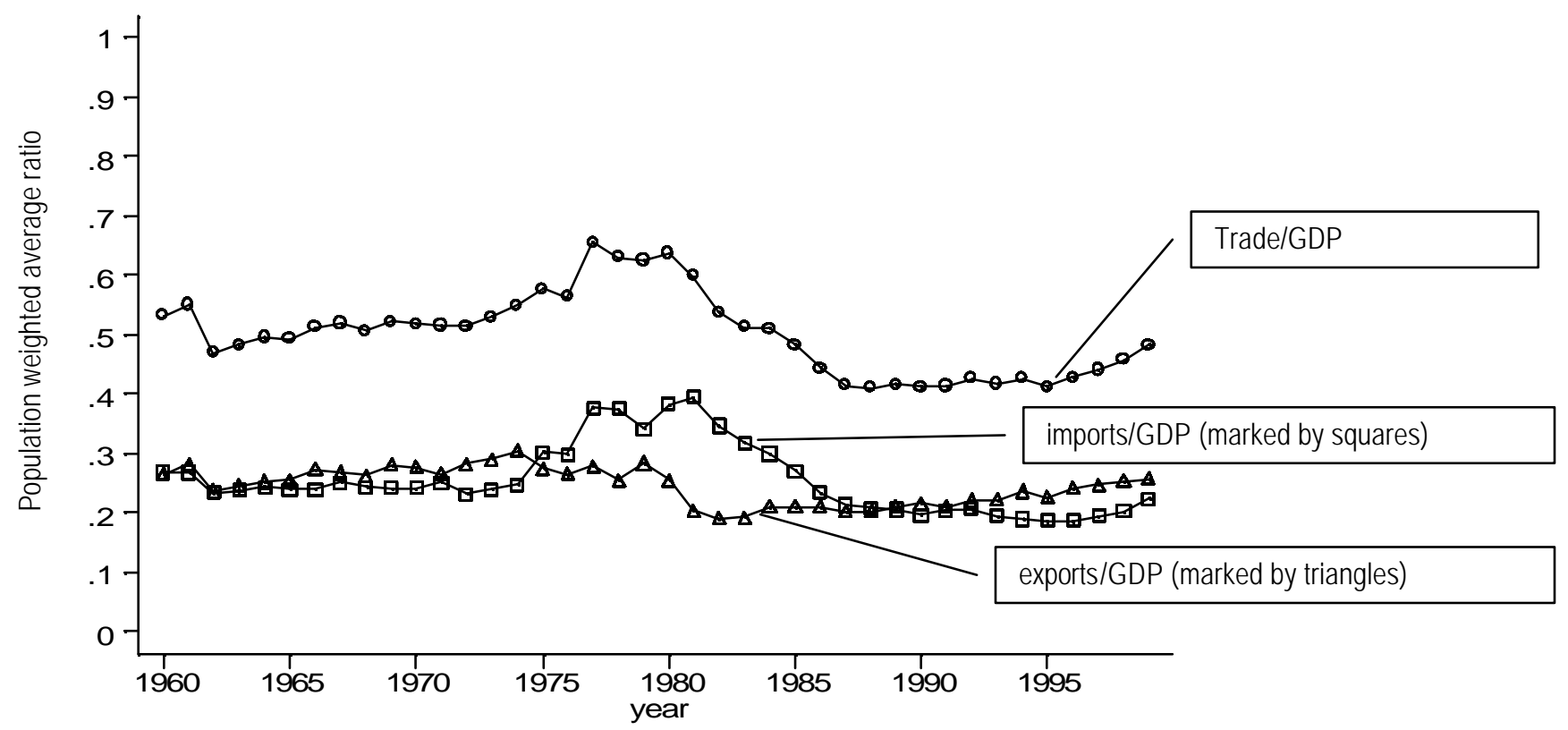

Of course, these graphs suggest that the content of exports and changes in world prices account for much of the story of the "globalization" of the "globalizers," rather than trade liberalization. It could be that trade liberalization in the 1980s by the "globalizers" caused both the shift in export content and the increases in the trade/GDP ratio. This is certainly implied in World Bank (2002), where "globalization" is equated with "[breaking] into world markets for manufactured goods." 20 We explore this question empirically by stratifying the countries in both our "most commodity dependent" and "least commodity dependent" groups based on the extent of their import tariff cuts, and then comparing changes in their trade/GDP ratios. ${ }^{21}$

Dollar and Kraay report decadal average tariffs in the 1980s and 1990s, and stratify countries based on whether they were among the top $33 \%$ of tariff cutters for which data are available. ${ }^{22}$

\footnotetext{
${ }^{20}$ Of course, as we discuss at greater length below, there is no theoretical reason why trade liberalization should be expected to result in a shift away from primary commodities in the short run-especially where the abundant factor in a country is some extractable natural resource. In the long run, a change in relative prices would probably result in such shifts, but trade liberalization is only relevant in this case if the pre-reform trade policy explicitly favors natural resource exports.

${ }^{21}$ We do not argue that tariffs are the only component in trade policy, but they are probably a reasonable indicator of a country's extent of trade liberalization, as Rodrik (2001) maintains. At the very least, it would be difficult to argue that a country among the world's leading tariff cutters is "antiglobalist" in its policy orientation.

${ }^{22}$ They identify these countries in table 2 of their original paper.
} 
We apply their classification to our "most commodity dependent" and "least commodity dependent" countries. (We cannot include countries in our sample that were not included in Dollar and Kraay's original sample_-which leaves 15 of our 34 "most commodity dependent" countries and 43 of our 74 "least commodity dependent" countries.)

Table 3 shows the resulting 2x2 matrix. Consider the experiences among the "most commodity dependent" countries included in the bottom row. Most were not able to achieve an increase in their trade/GDP ratio, whether they cut tariffs steeply or not. By comparison, the vast majority of the "least commodity dependent" countries saw increases in their trade/GDP ratios, regardless of whether they cut tariffs steeply or not.

\section{$\underline{\text { Table } 3}$}

\begin{tabular}{|c|c|c|c|}
\hline \multicolumn{2}{|c|}{$\begin{array}{l}\text { Annual change in trade/GDP between 1990s } \\
\text { and 1980s }\end{array}$} & $\begin{array}{l}\text { Top } 33 \% \text { of tariff } \\
\text { cutters }\end{array}$ & $\begin{array}{l}\text { Bottom } 67 \% \text { of } \\
\text { tariff cutters }\end{array}$ \\
\hline \multirow{5}{*}{$\begin{array}{l}\text { "Least Commodity } \\
\text { Dependent" }\end{array}$} & Mean & 0.011 & 0.006 \\
\hline & Median & 0.009 & 0.005 \\
\hline & $25^{\text {th }}$ percentile & 0.002 & -0.001 \\
\hline & $75^{\text {th }}$ percentile & 0.021 & 0.014 \\
\hline & N & 27 & 16 \\
\hline \multirow{5}{*}{$\begin{array}{l}\text { "Most Commodity } \\
\text { Dependent" }\end{array}$} & Mean & -0.005 & 0.000 \\
\hline & Median & -0.004 & -0.001 \\
\hline & $25^{\text {th }}$ percentile & -0.020 & -0.004 \\
\hline & $75^{\text {th }}$ percentile & 0.009 & 0.007 \\
\hline & $\mathrm{N}$ & 8 & 7 \\
\hline
\end{tabular}

Notes

The stratification on the vertical axis is as shown in table 2. The stratification on the horizontal axis is taken directly from Dollar and Kraay, who classify countries in table 2 of their paper based on the relative size of the reductions in their average import tariff rates between the late 1980s and the late 1990s. All statistics are unweighted. Due to the paucity of tariff data, only 15 of our 34 "most commodity dependent" countries, and 43 of our 72 "least commodity dependent" countries could be included. The 19 "most dependent" countries which had to be excluded for lack of tariff data are: Algeria, Angola, Bahamas, Burundi, DR Congo, Gambia, Iran, Liberia, Libya, Mali, Myanmar (Burma), Oman, Rwanda, Saudi Arabia, Solomon Islands, Somalia, Sudan, Suriname, and United Arab Emirates. The 29 "least dependent" countries which had to be excluded for lack of tariff data are: Afghanistan, Albania, Barbados, Bhutan, Bulgaria, Cambodia, Comoros, Djibouti, Dominican Rep, Fiji, Honduras, Hong Kong, Israel, Jordan, Kiribati, South Korea, Kuwait, Laos, Lebanon, Malaysia, Maldives, Malta, Mongolia, New Caledonia, Panama, Seychelles, St. Kitts and Nevis, Togo, and Vietnam. For more details, see text.

Of course, we do not maintain that export content is the only thing driving changes in the trade/GDP ratio. We simply highlight here that the content of a country's exports has affected whether or not its ratio of trade/GDP has increased since 1980. 


\section{Section III: Commodity dependence and economic growth}

There is disagreement about any causal mechanism explaining the negative relationship between economic growth and primary commodity dependence, but there is no disagreement about the association, at least over the time period that Dollar and Kraay consider. The different growth experiences during the 1980s and the 1990s of our "most commodity dependent" and "least commodity dependent" groups of countries are shown in table 4 . The commodity dependent countries grew more slowly in both decades - in fact, the overwhelming majority of them saw declines in PPP-adjusted per capita incomes during the 1980s. ${ }^{23}$

\footnotetext{
${ }^{23}$ The differences in aggregate GDP growth rates between the two groups are somewhat smaller, since the populations of the "most commodity dependent" countries grew about 0.6 percentage point faster on average. The population growth rate is not necessarily independent of commodity dependence.
} 


\section{Table 4}

\begin{tabular}{|c|c|c|c|}
\hline \multicolumn{2}{|c|}{$\begin{array}{l}\text { Average annual rate of growth of real PPP adjusted } \\
\text { GDP per person }\end{array}$} & $\begin{array}{l}\text { "Least Commodity } \\
\text { Dependent" }\end{array}$ & $\begin{array}{l}\text { "Most Commodity } \\
\text { Depedent" }\end{array}$ \\
\hline \multirow{5}{*}{ Growth during the $1980 \mathrm{~s}$} & Mean & 0.011 & -0.009 \\
\hline & Median & 0.005 & -0.013 \\
\hline & $25^{\text {th }}$ percentile & -0.007 & -0.024 \\
\hline & $75^{\text {th }}$ percentile & 0.030 & 0.004 \\
\hline & $\mathrm{N}$ & 65 & 32 \\
\hline \multirow{5}{*}{ Growth during the $1990 \mathrm{~s}$} & Mean & 0.015 & 0.000 \\
\hline & Median & 0.017 & 0.004 \\
\hline & 25th percentile & 0.000 & -0.016 \\
\hline & $75^{\text {th }}$ percentile & 0.032 & 0.016 \\
\hline & $\mathrm{N}$ & 68 & 28 \\
\hline
\end{tabular}

Notes

Growth experience for our "most commodity dependent" and "least commodity dependent" countries. The classification of countries is as shown in table 2. Average annual rates of growth of real PPP adjusted GDP per capita during the 1980s and during the 1990s are taken from he dataset underlying Dollar and Kraay (2001), which the authors were generous to share. The samples do not include all 34 "most commodity dependent" and 72 "least commodity dependent" countries because some countries had to be dropped for lack of income data. In the "most commodity dependent" group the observations which had to be dropped were: DR Congo (1990s), Liberia (1990s), Libya (1980s and 1990s), Saudi Arabia (1980s), Sierra Leone (1990s), Somalia (1990s), and United Arab Emirates (1980s); and in the "least commodity dependent" group: Afghanistan (1980s and 1990s), Côte d'Ivoire (1980s), Djibouti (1980s), Guyana (1980s), Kiribati (1980s), Kuwait (1980s), Lebanon (1980s and 1990s) and New Caledonia (1980s and 1990s). All statistics are unweighted. For more details, see text.

Dollar and Kraay's use of changes in the trade/GDP ratio to measure "participation in globalization" greatly overestimates the importance of policy intention on trade openness because policy intention has no effect on world prices, which in turn affect a country's export revenues. Furthermore, commodity dependence, which has brought declining export revenues since the early 1980s, is correlated with slower growth. The quantitative effects of this missing variable problem on growth are significant, as table 5 shows. The left column reproduces the empirical result reported in Dollar and $\mathrm{Kraay}^{24}$, with a one-hundredth point increase in the trade/GDP ratio over a decade being associated with about half a percentage point faster annual growth in income per person. Columns 3 and 4 show results of the same regression, except we

\footnotetext{
${ }^{24}$ See table 6 in their original paper.
} 
also include variables that indicate the content of exports. These variables "soak up" the apparent importance of "openness" dramatically. ${ }^{25}$

\section{$\underline{\text { Table } 5}$}

\begin{tabular}{|c|c|c|c|c|}
\hline $\begin{array}{l}\text { Dependent variable: Average annual growth } \\
\text { in real PPP GDP per capita over each } \\
\text { decade }\end{array}$ & $\begin{array}{l}\text { Original IV } \\
\text { Regression }\end{array}$ & $\begin{array}{c}\text { As column 1, } \\
\text { without } 8 \\
\text { observations (see } \\
\text { table notes) }\end{array}$ & $\begin{array}{l}\text { As column 2, plus } \\
\text { dummy for "least } \\
\text { commodity } \\
\text { dependent" }\end{array}$ & $\begin{array}{c}\text { As column 2, plus } \\
\text { lagged share of } \\
\text { manufactures } \\
\text { exports in total }\end{array}$ \\
\hline \multirow{2}{*}{$\begin{array}{l}\text { Lagged annual income growth (instrument: } \\
\text { log average income per person, previous } \\
\text { decade) }\end{array}$} & 0.782 & 0.677 & 0.447 & 0.401 \\
\hline & $(0.305)^{\star}$ & $(0.278)^{*}$ & $(0.526)$ & $(0.732)$ \\
\hline \multirow{2}{*}{$\begin{array}{l}\text { Average annual change in trade/GDP ratio } \\
\text { since last decade (instrument: trade/GDP } 2 \\
\text { decades ago) }\end{array}$} & 0.474 & 0.535 & 0.203 & 0.254 \\
\hline & $(0.217)^{\star}$ & $(0.206)^{*}$ & $(0.267)$ & $(0.557)$ \\
\hline \multirow{2}{*}{ Dummy variable: 1980s } & -0.018 & -0.016 & -0.013 & -0.012 \\
\hline & $(0.006)^{\star \star}$ & $(0.006)^{\star \star}$ & $(0.010)$ & $(0.012)$ \\
\hline \multirow{2}{*}{$\begin{array}{l}\text { Dummy variable: "Least commodity } \\
\text { dependent" (as listed in table 2) }\end{array}$} & & & 0.011 & \\
\hline & & & $(0.011)$ & \\
\hline \multirow{2}{*}{$\begin{array}{l}\text { Average share of manufactures exports in } \\
\text { total merchandise exports, previous decade }\end{array}$} & & & & 0.016 \\
\hline & & & & $(0.030)$ \\
\hline \multirow{2}{*}{ Constant } & 0.004 & 0.004 & -0.000 & 0.002 \\
\hline & $(0.004)$ & $(0.004)$ & $(0.005)$ & $(0.003)$ \\
\hline Observations & 187 & 179 & 177 & 179 \\
\hline
\end{tabular}

Standard error of coefficient estimates (in parentheses) are robust to heteroskedasticity; they are calculated using the Huber-White estimator of the variance.

${ }^{*}$ significant at $5 \%$; ** significant at $1 \%$

Notes

Log income levels (real annual PPP GDP per capita, averaged over each decade), average annual income growth, and trade/GDP ratios are taken from the dataset underlying Dollar and Kraay (2001), which the authors were generous to share. The functional specification is identical to the one employed by Dollar and Kraay. All growth rates either cover income growth over the 1980s or over the 1990s. The dummy variable in row 4 of the table indicates whether or not the observation is of growth during the 1980s. Column 1 exactly replicates the results reported in table 6 of Dollar and Kraay (2001). Note that although there are 187 observations in this regression (90 countries during the 1980s, and 97 during the 1990s), export content data are not available for eight of these observations-China (1980s), Lesotho (1980s and 1990s), Luxembourg (1980s and 1990s), Swaziland (1990s), and Taiwan (1980s and 1990s). Dropping these eight observations, however, does not dramatically alter the results, as can be seen by comparing the coefficient estimates and standard errors in columns 1 and 2. However, comparing the coefficient estimates in columns 2 and 3 illustrates the importance of export content in driving Dollar and Kraay's results. Specifically, the attenuation of the coefficient estimates in row 2 from one column to the next indicates the exent to which Dollar and Kraay's conclusions about the importance of trade liberalization are confounded by the effects of primary commodity dependence. In our discussion in the previous section, we calculated the share of commodities in total exports ourselves, using trade data disaggregated by SITC available from Statistics Canada (1999). However, since these data are not available from before 1980, we use the manufactures export proportion reported in World Bank (2001a) in these regressions. Although we would have preferred if our SITC-specific export data had gone back before

25 The large standard error estimates are probably the result of multicollinearity in the data, caused by the extensive overlap between lagged trade/GDP ratio and export content. 
1980, we note that the two data series are almost perfectly consistent over those observations for which they are both available. The dummy variable in row 5 takes a value of one if the country is in our "least commodity dependent" group. The countries in this group are listed in table 2. However, some of them were dropped from the regression for lack of data. All the country-decade observations included in these regressions are listed in Appendix List D. For more details, see text.

Why have the "most commodity dependent" economies not grown? Most of the issues raised in the enormous literature on the growth effects of commodity dependence have nothing to do with the "globalization debate." We summarize here four alternative explanations, which are not mutually exclusive.

\section{Commodity dependence, fiscal problems, and global commodity prices}

The stagnant growth which we observe among the "most commodity dependent" countries might be shorter-run effects of the recent declines in the world prices of their exports. Governments that rely on natural resource exports for their revenues may be forced to run higher deficits or reduce public consumption and investment when prices are low. Declining export revenues also reduce the capacity of firms to import productive inputs, especially if there are credit constraints or if the downward trend in prices is expected continue. ${ }^{26}$

\section{Commodity dependence, politics, institutions, and long run endogenous growth}

In the longer run, slow growth may reflect lost opportunities for knowledge "spillovers," poor incentives for human capital investment, rent seeking of predatory governments, non-increasing returns (compared to manufactured products and services), and limited secular improvements in production efficiency attributable to technological change. ${ }^{27}$

Stories of knowledge spillovers usually begin with the idea that people learn by doing-and therefore that employment both utilizes and generates specialized human capital. The identifying assumption necessary to invoke knowledge spillovers to explain slower long run growth in commodity-dependent countries is that employment in the production of higher valueadded goods (or of certain services) creates more tacit knowledge and more learning by doing

\footnotetext{
${ }^{26}$ Hausmann (1995) discusses these effects in the case of Venezuela.

${ }^{27}$ The literature exploring the causal relationships between dependence on natural resources (or low value-added primary commodities more generally) and slow growth stretches back to some of the earliest studies on economic growth. Among the more authoritative reviews is Gelb (1988), although important theoretical and empirical extensions have since been offered by Auty (1990 and 2001); Auty and Mikesell (1998); Birdsall, Pinckney and Sabot (2000); Matsuyama (1992); and Sachs and Warner (1997, 1999, and 2001). A number of case studies have also emerged which offer insights; several re collected, for example, in Mayer, Chambers, and Farooq (1999).
} 
than the production of lower value-added goods. As a result, the growth of the human capital stock in commodity-dependent countries remains slow as long as they remain commodity dependent, to the extent that a portion of their labor force remains tied up in the primary sector. As Sachs and Warner (1997) point out, however, since the production of some primary goodsmost notably, oil and gas - ties up only a tiny proportion of the labor force, this explanation is not necessarily relevant to the experience of all primary producer countries.

Others, including Birdsall, Pinckney, and Sabot (2000) explore the effects of primary commodity dependence and natural resource wealth on incentives to invest in human capital, particularly among the poor. Where large natural resource deposits are available, the rents tend to accumulate in the hands of government or a small well connected oligarchy. This gives rise to policy distortions which ultimately reduce returns to human capital investment, slowing the growth of the human capital stock. Gylfason (2001) shows the empirical regularity between high natural resource wealth and low human capital investment.

More generally, the fact that commodity production involves a finite factor (for example, land in the case of agriculture - or, in the case of fossil fuel or mineral extraction, the fuels or minerals themselves) necessarily implies that returns to other factors cannot be increasing (at least, not indefinitely). It may be easier in the production of high value added goods to escape the tyranny of finite factors through technological innovation to improve overall efficiency. This can have two effects. First, it can produce a steady decline in the relative value of primary inputs (for example, if less and less energy becomes necessary to produce the same manufactured products over time). Primary producers, in such circumstances, would see a steady decline in their terms of trade. $^{28}$ At the same time, the presence of increasing returns in higher value added sectors may touch off a process of sustained endogenous growth, where higher levels of production lead to greater incentives for investment and more technological innovation, which lead in turn to faster growth. Missing out on this virtuous cycle, countries which remain dependent on commodities will fall farther and farther behind manufactured goods producers.

\footnotetext{
${ }^{28}$ Prebisch (1950) and Singer (1950) hypothesized such a secular trend, and the resulting empirical debate continues to rage.
} 
Finally, political mechanisms can also be invoked. Some commodities_including minerals, gems, or fuels - are geographically localized, and control of the space in which they are deposited generates enormous rents. This produces a number of difficulties. For example, it makes governments less accountable to their populations, since their source of revenue remains assured as long as they remain dominant in terms of the physical means of coercion. As the historical experiences of many Latin American, Middle Eastern, and African countries illustrates, corruption and dictatorship flourish in oil and diamond-rich soils. ${ }^{29}$ Also, the presence of large local natural resource deposits may lead to physical conflict between competing rent-seeking groups. $^{30}$

\section{Commodity traps and poverty traps}

Short run management of price effects combined with long run institutional handicaps may produce one or another "trap" or low- level equilibrium. For example, "Dutch Disease" describes one trap (viz., through a decrease in the purchasing power of traded goods over non-traded goods and services during boom times) by which primary commodity dependence today precludes investment in other forms of production, thereby resulting in primary commodity dependence tomorrow. To the extent that some countries, due to accidents of history and geography, begin with a comparative advantage in primary goods, and become dependent on these commodities, the commodity trap may also become a poverty trap. ${ }^{31}$

\section{Conclusion}

The empirical evidence that Dollar and Kraay bring to the "globalization debate" is valuable, but mostly for reasons orthogonal to "globalization." Our evidence suggests that the "closedness" of countries dependent on primary commodities for their export revenues is more apparent than

\footnotetext{
${ }^{29}$ There is disagreement about the extent to which corruption and dictatorship cause slow growth, rather than the other way around. This debate is not immediately relevant to our point.

${ }^{30}$ These issues have been explored, for example, by de Soysa (2000); Collier and Hoeffler (1998); and Elbadawi and Sambanis (2000).

${ }^{31}$ This is particularly true for one set of commodity dependent countries - those with large natural resource deposits. Almost no country with large natural resource deposits ended up on Dollar and Kraay's list of "globalizers." In a separate paper, Hamoudi shows that countries with "point source natural resources" (as classified by Isham and others [2002]) have experienced particularly evanescent growth paths, with income in real terms peaking during the early 1980s. The concavity is most pronounced for our "most commodity dependent" countries. "Point source natural resource" deposits are largely exogenous to government policy.
} 
real, the result in no small part of the shift in global demand for primary commodities and the structure of world prices beginning around the world 1980s.

The "commodity curse" may have little to do with trade policy. Of course, trade policy may have some bearing on the prospects for diversification away from primary commodities, assuming that labor abundance and favorable real exchange rates could be expected to make some commodity dependent countries attractive sites for foreign direct investment. If the main barrier to higher value added productive enterprises in these countries is a lack of capital and other factor inputs, or a lack of domestic demand, then trade and capital account liberalization might be able to induce sufficient foreign investment and export demand to overcome these obstacles. Then, the proliferation of labor-intensive industries could touch off a process of sustained endogenous growth, assuming the countries would maintain their comparative advantage in the products of these industries for a sufficient length of time. This is widely believed to be the story of East Asia's economic "miracle" in the generation between the late 1960s and late 1990s. ${ }^{32}$ However, in this (particularly popular) story about the benefits of "globalization," it is increases in exports that were truly important. "Opening up" is important in this story only insofar as it is difficult to restrict imports and promote exports simultaneously. But there are many_including the World Bank (1993)—who argue that East Asia's "miracle" countries managed to do exactly that. ${ }^{33}$

The problem is that it is difficult to draw policy lessons from the experience either of East Asia's "miracle" countries or Dollar and Kraay's "globalizers," for two reasons. First, it is not obvious how a country can go about "globalizing." Dollar and Kraay (2002), as well as the World Bank (2002), have begun to describe every aspect of government policy as relevant to "globalization"-_including health, education, social protection, governance, public institutions, infrastructure and other public goods, trade policy, bureaucratic efficiency, macroeconomics, even migration policy. We have long known that in every country mired in poverty, something

\footnotetext{
32 Although there are others including Bloom, Canning, and Malaney (1999) who have other explanations for the "miracle."

${ }^{33}$ Many other countries, which have tried similar export promotion schemes (duty drawbacks, export processing zones, and so on) have not enjoyed the same success, probably for lack of the administrative capacity to manage the process and prevent abuses of it.
} 
has been going wrong in one or more aspects of one or more of these policies. It doesn't add much to simply recast these many failures to develop as failures to "globalize."

Second, as we have shown, many of the "non-globalizers" are particularly rich in point-source natural resources. There is no evidence at all that trade liberalization helps countries deal with the "commodity curse." Scholars and policy makers who are serious about contributing to the "elusive quest for growth" in these countries would do better focusing their attention on more fundamental development issues, rather than being distracted by panaceas or getting lost in the ideologically driven "globalization debate." 


\section{$\underline{\text { References }}$}

Auty RM (1990) Resource Based Industrialization: Sowing the oil in eight developing countries Oxford University Press: New York.

Auty RM and Mikesell RF (1998) Sustainable Development in Mineral Economies Oxford University Press and Clarendon Press: Oxford and New York.

Auty RM (2001) “The Political Economy of Resource-Driven Growth” European Economic Review 45(4-6): 839-846.

Birdsall N; Pinckney T; and Sabot R (2000) "Natural Resources, Human Capital, and Growth" (mimeo) Carnegie Endowment for International Peace: Washington, DC.

Bloom DE; Canning D; and Malaney PN (1999) "Demographic Change and Economic Growth in Asia" (mimeo) Center for International Development at Harvard University. Available on- line at http://www.cid.harvard.edu/cidwp/015.htm.

Collier P and Hoeffler A (1998) "On Economic Causes of Civil War" Oxford Economic Papers 50(4): 563-573.

de Ferranti D; Perry GE; Lederman D and Maloney WF (2002) From Natural Resources to the Knowledge Economy. Latin American and Caribbean Studies Viewpoint Series. World Bank: Washington, DC.

de Soysa I (2000) "Natural Resources and Civil War: Shrinking pie or honey pot?" Presented at the $41^{\text {st }}$ annual Convention of the International Studies Association, March 14-18, 2000, Los Angeles, CA.

Dollar D (1992) “Outward Oriented Developing Countries Really Do Grow More Rapidly: Evidence from 95 LDCs, 1976-85” Economic Development and Cultural Change 40(3): 523-44

Dollar D and Kraay A (2001) “Trade, Growth, and Poverty." (mimeo) World Bank, Washington, DC. Available on-line at http://www.worldbank.org/research/growth/pdfiles/Trade5.pdf

Easterly (2001) The Elusive Quest for Growth: Economists adventures and misadventures in the tropics. MIT Press: Washington, DC.

Elbadawi I and Sambanis N (2000) "Why Are There So Many Civil Wars in Africa? Understanding and preventing violent conflict" Journal of African Economies 9(3): 244-269.

Frankel JA and Romer D (1999) “Does Trade Cause Growth?” American Economic Review 89(3): 379-99.

Gavin M and Hausmann R (1998) "Nature, Development, and Distribution in Latin America: Evidence on the role of geography, climate, and natural resources" Inter-American Development Bank Working Paper No. 378. IADB: Washington, DC 
Gelb AH (1988) Windfall Gains: Blessing or curse? Oxford University Press: New York.

Gylfason T (2001) "Natural Resources, Education, and Economic Development" European Economic Review 45(4-6): 847-859.

Hausmann R (1995) "Dealing with Negative Oil Shocks: The Venezuelan experience in the eighties" Inter-American Development Bank Working Paper No. 307. IADB: Washington, DC

Heston A and Summers R (1995) "Penn World Tables, Mark 5.6" Center for International Comparisons at the University of Pennsylvania: Philadelphia. Available online at http://www.pwt.econ.upenn.edu

Isham J; Pritchett L; Woolcock M; Busby G (2002) "The Varieties of the Rentier Experience: How natural resource endowments affect the political economy of economic growth" (mimeo) Department of Economics, Middlebury College: Middlebury, VT

Manzano O and Rigobon R (2001) “Resource Curse or Debt Overhang?" NBER Working Paper no. 8390. National Bureau of Economic Research: Cambridge, MA.

Matsuyama K (1992) "Agricultural Productivity, Comparative Advantage, and Economic Growth" Journal of Economic Theory 58(2): 317-334.

Mayer J; Chambers B; and Farooq A, eds (1999) Development Policies in Natural Resource Economies Elgar and UNCTAD: Cheltenham, UK and Northampton, MA.

Prebisch R (1950) The Economic Development of Latin America and its Principal Problems United Nations: New York.

Rodrik D (2000) "Comments on 'Trade, Growth, and Poverty,' by D. Dollar and A. Kraay" (mimeo) Harvard University: Cambridge, MA. Available on-line at: http://ksghome.harvard.edu/ .drodrik.academic.ksg/Rodrik\%20on\%20Dollar-Kraay.PDF

Rodrik D (2001) "Globalization, Growth, and Poverty: Is the World Bank beginning to get it?" (mimeo) Harvard University: Cambridge, MA. Available on-line at: http://ksghome.harvard.edu/ .drodrik.academic.ksg/WB\%20oped.pdf

Sachs JD and Warner AM (1995) "Economic Reform and the Process of Global Integration" Brookings Papers on Economic Activity 1995(1): 1-95.

Sachs JD and Warner AM (1997) "Natural Resource Abundance and Economic Growth" (mimeo) Center for International Development, Harvard University: Cambridge, MA.

Sachs JD and Warner AM (1999) "The Big Push, Natural Resource Booms, and Growth" Journal of Development Economics 59(1): 43-76.

Sachs JD and Warner AM (2001) "The Curse of Natural Resources" European Economic Review 45(4-6): 827-838. 
Singer HW (1950) "The Distribution of Gains Between Investing and Borrowing Countries" American Economic Review 40(2):473-485

Statistics Canada (1998) World Trade Analyzer, CD-ROM. International Trade Division, Statistics Canada: Ottawa.

World Bank (2001) Global Economic Prospects and the Developing Countries. World Bank: Washington, DC.

World Bank (2001a) World Development Indicators CD-ROM and print. Development Data Group: Washington, DC

World Bank (2002) Globalization, Growth, and Poverty: Building an inclusive world economy Oxford University Press: Washington, DC. 
Page 28 


\section{Appendix Figure A}

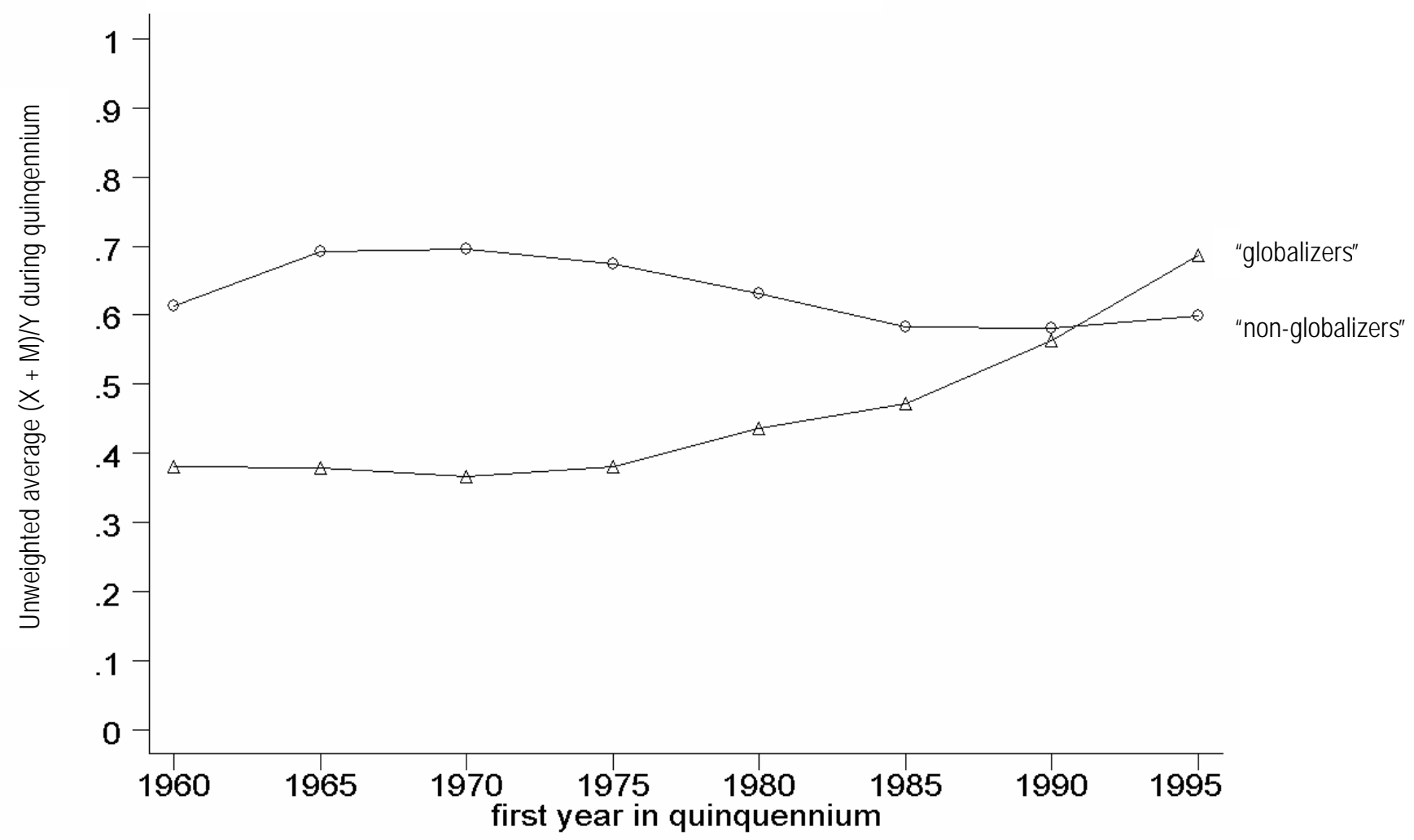

\section{$\underline{\text { Appendix Figure B }}$}

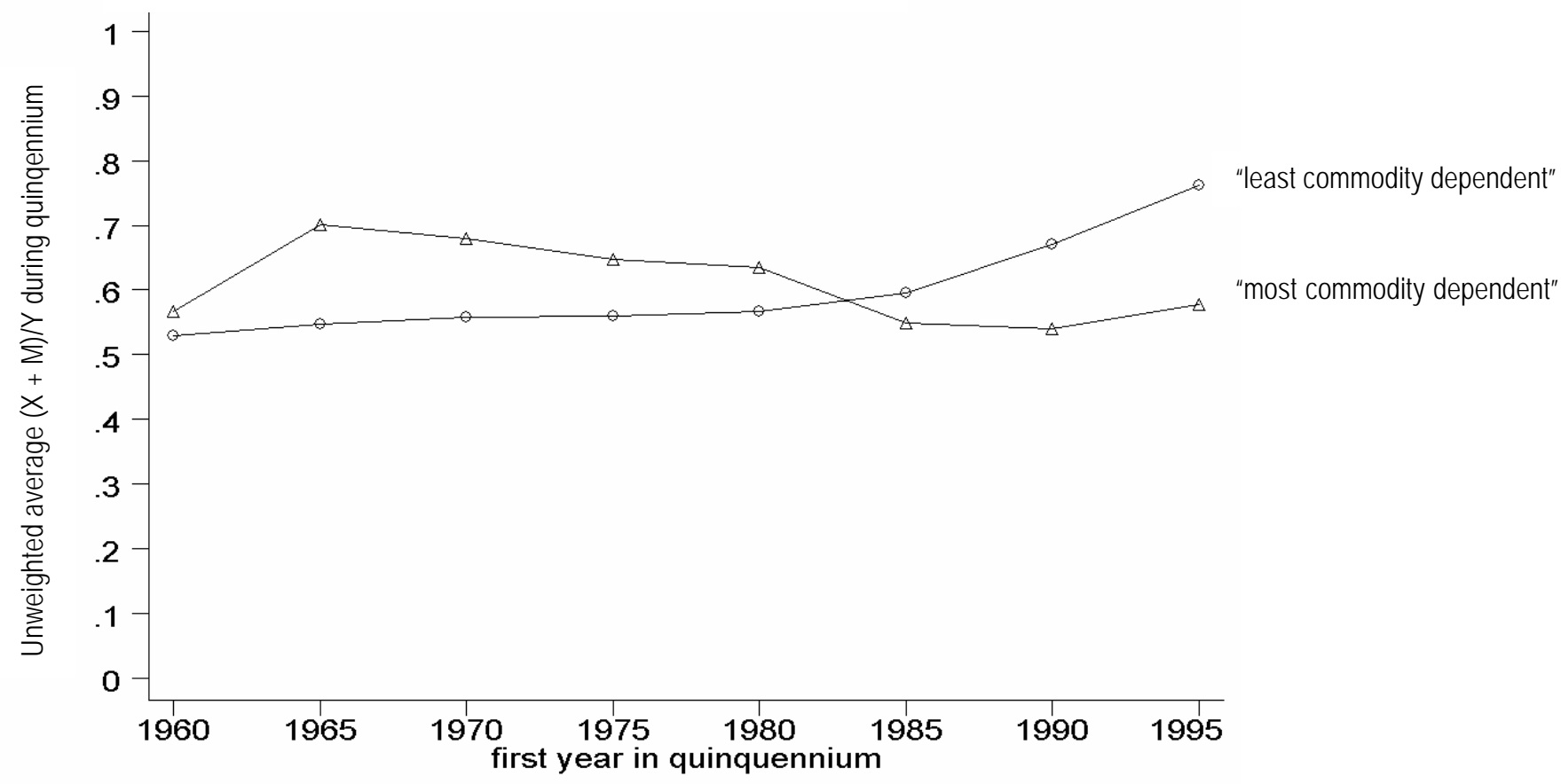




\section{$\underline{\text { Appendix Figure C }}$}

\section{a. Least Commodity Dependent Countries}

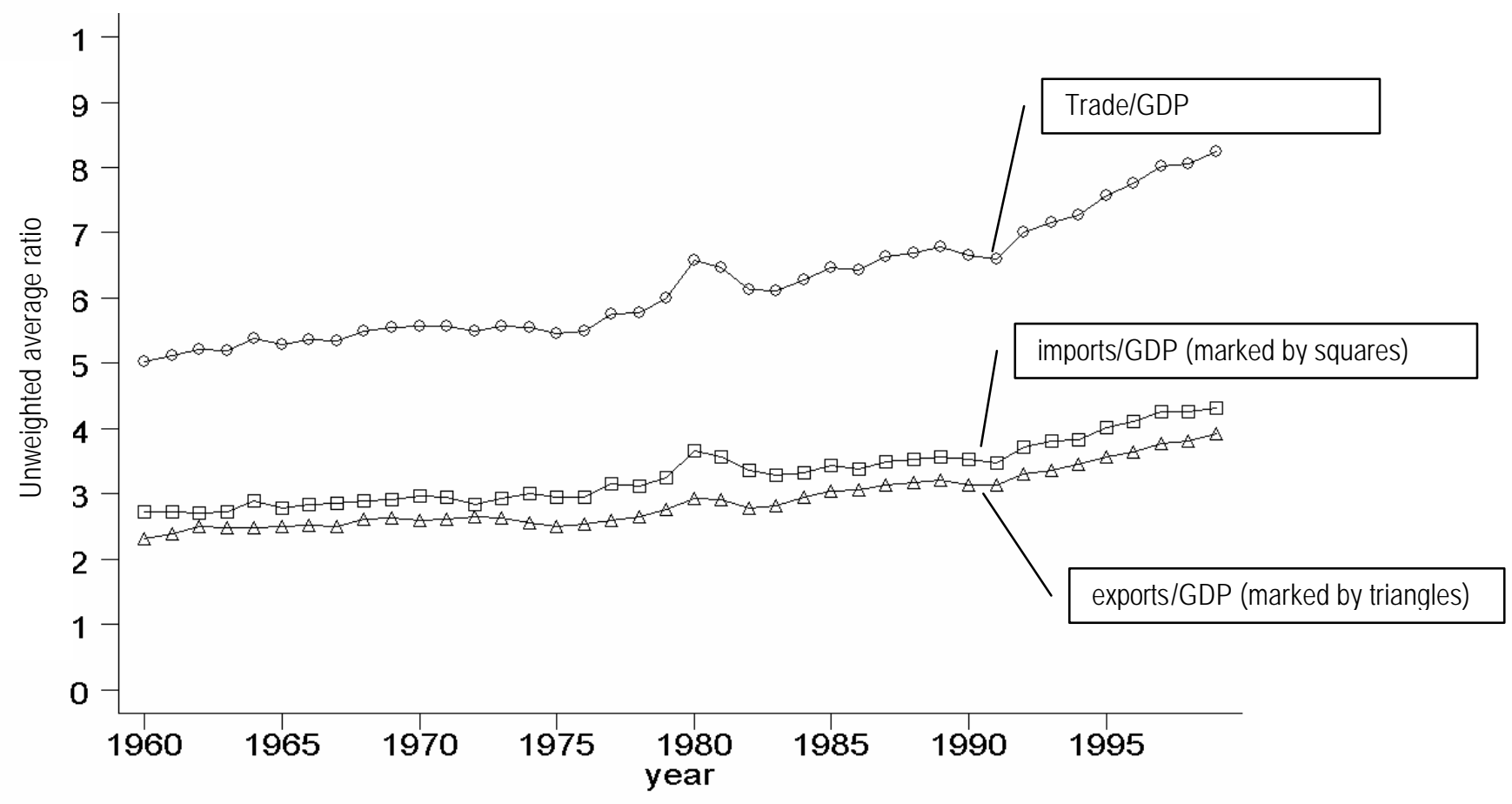

b. Most Commodity Dependent Countries

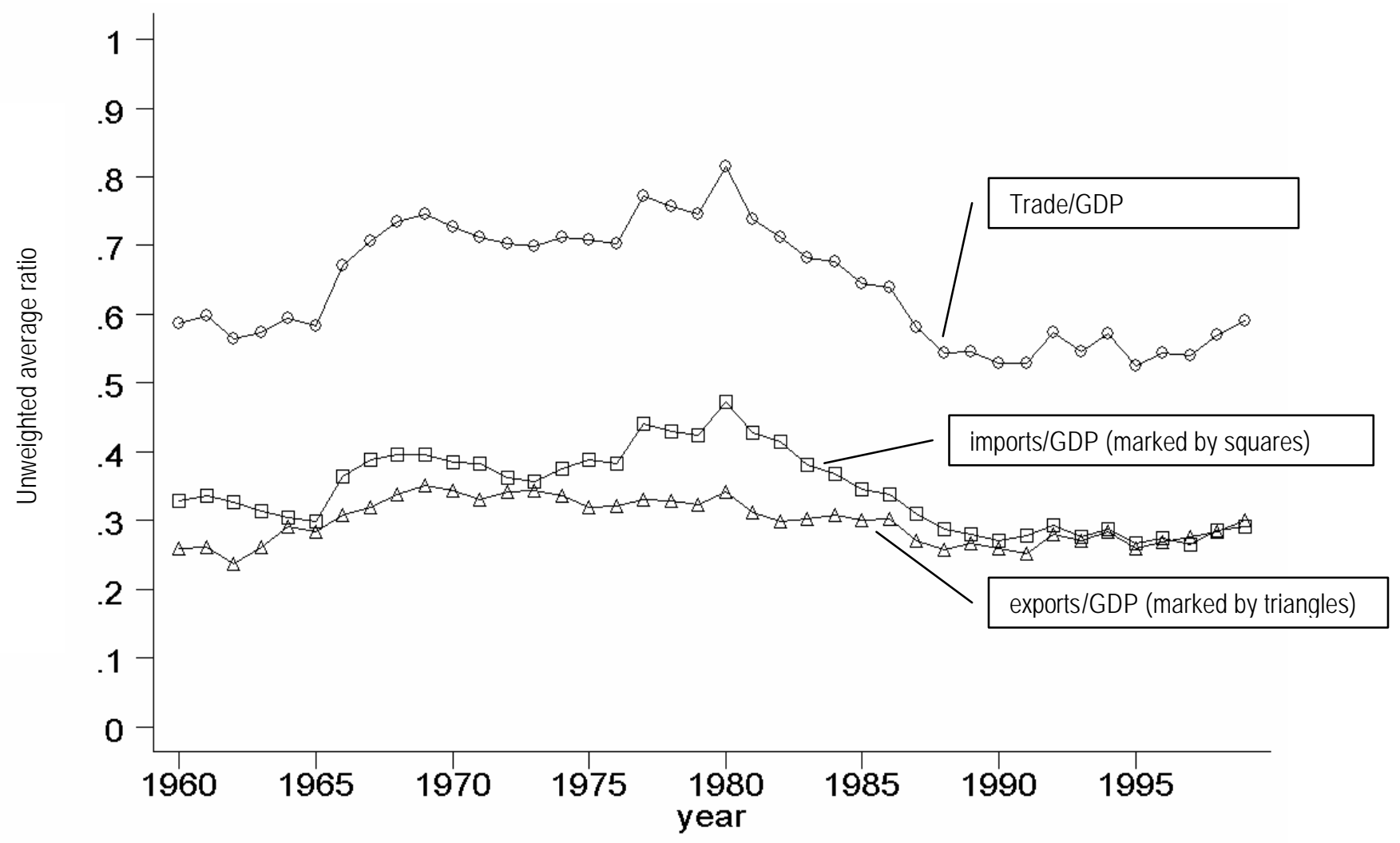

